\title{
Implementation of Strategic Management In The Establishment of Characters In Basic School
}

\author{
Siti Ayu Suprapti, Yatim Riyanto \\ Universitas Negeri Surabaya \\ Surabaya, Indonesia \\ ayusita087@gmail.com
}

\begin{abstract}
The purpose of this study was to determine and analyze: (1) management strategies in the formation of student character, (2) implementation of strategic management in the establishment of characters in basic school. This research is a qualitative descriptive study. The method that is used in this research are observation, interviews, and documentation. Examination of the validity of the data is done by triangulation technique, which is by checking information on the results of interviews with documentation and observation. The results in this study indicate that each elementary school has a strategy in character building. Teachers as managers in the implementation of strategic management in the formation of character students are expected to be able to plan the right strategy, so that the goals of the school can be achieved. Future planning should be applied optimally. After a good implementation, it still requires an evaluation to improve and develop the implementation of the management strategy in the formation of the character of students in the implementation of management strategies in the formation of student character.
\end{abstract}

\section{Keywords - strategic management, student character}

\section{INTRODUCTION}

A plan designed to improve the system is a technique and the best strategy for solving problems in an organization. Strategy for some organizations is a way to overcome and anticipate any problems that arise and provide opportunities to improve the existing system in the organization for the future. Thus the strategy must be able to provide a clear and directed picture of what needs to be carried out by an organization. Strategy requires a mature developer in its implementation, so that it is expected to effectively improve a system and maximize the work of a strategy. These expectations will pay off with the achievement of goals that have been planned in advance.

In a good strategy, there is good coordination of the work team to achieve the goals effectively. HR performance is very calculated in the implementation of the strategy, so that the goals of the organization will be achieved maximally. With this in mind, it is necessary to have a management strategy that is able to regulate the course of the strategies that have been implemented. Strategy management is the art and science of strategic planning, the implementation of planned strategies, and the evaluation of the implementation that has been planned and expected to be able to achieve the objectives that have been formulated in a plan that has been prepared through various considerations that are good and beneficial for an organization. Strategy management is the highest management activity that is usually compiled by the board of directors and carried out by the organization's executive team.

Strategy management speaks of the big picture. The core of strategy management is to identify the goals of the organization, its resources, and how the available resources can be used most effectively to meet strategic objectives. Strategy management must be able to provide guidance for decision making in organizations. This is a continuous and continuous process.

Character is a behavior that is characteristic and character that is typical of someone. The character and character will become distinctive and long lasting attached to someone if it is always carried out and it goes on and on. The Ministry of National Education Language Center means that character is as innate as heart, soul, personality, character, behavior, personnel, character, temperament, temperament, and character.

From Daryanto has been stated about the urgency of character education in schools referring to Law No. 20 of 2003 concerning National Education System states [1]that National Education functions to develop the ability and shape of dignified national character and civilization in order to educate the lives of the nation, aiming for the development of potential learners to become faithful and fearful people of God Almighty, noble, healthy, knowledgeable, capable, creative, independent, and become democratic and responsible citizens.

From this description character education in schools is based on a need and is urgent in keeping up with the times. Given the increasingly complex development of the times, there needs to be a filter in addressing students' disciplinary attitudes. When talking about education at school, there seem to be some people who only see quality from one side, namely the academic side. If students are not capable in the academic aspect, the guardian will be optimally endeavored to achieve achievement in the academic field. While empirical data shows that academic quality will be easily broken if it is not accompanied by a full character. Both aspects will be more 
useful and effective if they can run continuously with each other, so that they can strengthen students in their personal and emotional development.

\section{METHOD}

In this study, we used a qualitative approach. A qualitative approach uses a deductive mindset, which is a way of thinking from the general to the specific. Qualitative research methods use human instruments with inductive data analysis based on facts, then constructed into hypotheses or theories.

Researchers use a qualitative approach because researchers want to know how to implement strategic management in character building in elementary schools. From the formulation of the problem, the researcher can find out that the question of how it requires a long descriptive answer. So this is where researchers use a qualitative approach.

Descriptive length in this study is a type of case study because researchers will conduct detailed testing of a management strategy that aims to characterize students. According to Bogdan and Bikien is a study by testing in detail about something, both individuals (people) relating to development and criteria, setting, bookkeeping and storing documents such as photos, videos, or any attachment files, or even certain events [2] that contain interesting elements for further research.

The researcher will observe the implementation of strategies that have been designed for the purpose of character building for students in elementary schools. The important meaning of the implementation of the strategy management is the formation of students' character in social matters. Act with older people, respect each other's differences, and love the younger ones.

In this study we used a qualitative approach. A qualitative approach uses a deductive mindset, which is a way of thinking from the general to the specific. Qualitative research methods use human instruments with inductive data analysis based on facts, then constructed into hypotheses or theories.

Researchers use a qualitative approach because researchers want to know how to implement strategic management in character building in elementary schools. From the formulation of the problem, the researcher can find out that the question of how it requires a long descriptive answer. So this is where researchers use a qualitative approach.

Descriptive length in this study is a type of case study because researchers will conduct detailed testing of a management strategy that aims to characterize students. According to Bogdan and Bikien is a study by testing in detail about something, both Individuals (people) relating to development and criteria, setting, bookkeeping and storing documents such as photos, videos, or any attachment files, or even certain events [2] that contain interesting elements for further research.
The researcher will observe the implementation of strategies that have been designed for the purpose of character building for students in elementary schools. The important meaning of the implementation of the strategy management is the formation of students' character in social matters. Act with older people, respect each other's differences, and love the younger ones.

\section{RESULTS AND DISCUSSION}

\section{A. Strategic Management in The Establishment of Characters}

The term strategic management refers to the management process for formulating a vision, setting goals, formulating strategies, implementing and implementing strategies, and making adjustments to adjustments in their inappropriate vision, objectives, and strategies. Strategy management can be defined as a series of decisions and actions to formulate, implement, and evaluate decisions across functions designed to achieve a company's goals. According to David[3], strategy management can be defined as art and knowledge in formulating, implementing, and evaluating cross-functional decisions that enable an organization to achieve its goals. According to Mainardes in international journals argue [4]that the factors that make up the definition of strategy in the future vision of managers Regarding strategic management topics, further studies can serve to refine the current concept.

From the data that the researchers have collected through interviews, the management of students' character building strategies also goes through three stages, namely:

\section{Formulate}

At this stage, it is formed because of the background of students being disorganized while in school, behavior that is not good for older friends, peers, and junior. Schools need to look back at the vision and mission of the school to create strategies to improve student character. As a basis for students' intelligence, character has an important role in the development of intelligence. According to Agung in international journals said that character education that focuses on developing students'[5] identities becomes smart and has character because characters need to be forced through formal and informal education. From the description, it is explained that there is a need for good management of the implementation of character education in formal schools. It is important to carry out character education starting from elementary school, remembering when elementary school age is the age of gold for child development. 


\section{Implement}

Pala in an international journal said [6]that character education efforts might be effective when implemented rigorously and with a scientific basis. Schools must focus on running a character-based curriculum. So that every learning carried out contains a moral message that can improve the quality of the character of students. As the opinion of Novianti in international journals argues [7]that character education needs to be included in all subjects for better and more visible results, and discussion of virtues with various methods must be integrated in teaching. So that this will be easily accepted by students and students are accustomed to carrying out these good habits and are expected to shape their character.

\section{Evaluate}

Agboola in an international journal explained [8]that some of the problems of character education are the lack of reliable and valid evaluations to justify their effects; therefore, it will be useful for future research that places more weight on assessment. From the description, it is expected that there will be a valid assessment rubric in measuring the success of the strategy in the formation of student character. Of the various types of student characters that exist, there needs to be a standard in determining the success of a strategy. As according to Park in international journals argues about some of the standard characters [9] that students should have, including self-confidence, enthusiasm, gratitude, curiosity, and love are closely related to life satisfaction, and strong simplicity and intellectual.

\section{B. Implementation of Strategic Management in The} Establishment of Characters in Basic School

Primary school is an early level of education for student character formation. Students who are embedded in their good character will be able to process every behavior wherever they are. In addition, if students have been embedded in good character from an early age, it will be wiser to take decisions and carry out each job. In the first observation conducted by researchers, data were obtained from the field that there were unique habits. Students always obey the teacher. Students will apply a smile, greetings, greetings if they meet with the teacher. Teachers often remind their students to drink and eat while sitting. In addition, good behavior in the mosque has become a routine habit. Even so, there are still students who haven't done the habit well. For example, there are still students who eat while standing, not yet orderly when praying, and not yet orderly in class when learning takes place. This requires a good management strategy to reorganize the bad character. In this case, it is more important to implement the strategy management. According to Alharthy in international journals said [10]that important factors of strategy implementation are the top features in Management studies, because it can change the failure to succeed the strategy, providing all the factors that have been identified and managed from the initial stage. Good management greatly determines the success of the planned strategy.

The teacher has an important task in shaping the character of students, so that life in society and state can be more organized. Indirectly, young people who have good character can build a better country. This is the reason for integrating character education in citizenship lessons. This is in accordance with the opinion of Althof in international journals [11] that character education can serve as a foundation for civic education, they are far from isomorphic. The plan will work well if there is a good character arrangement. Hidayati Based on the questionnaire distributed to the teacher, it shows [12]that the character of the education curriculum is currently in good condition, with a percentage of $80.66 \%$. However, based on interviews, character education is less effective and not enough to be able to build positive character for students. This condition occurs because teachers have not been able to integrate character values in learning, are less able to provide a good role model for students about how to have character, and character education has also not taken place comprehensively. From these results, it is necessary to have good planning to create a curriculum that aims to improve the quality of student character. Because Aslan in an international journal argues [13]that education is about more than academic learning. From the description of the opinion, it is hoped that there is an important essence in education, that is, there are characters that can improve life. Character education can be carried out without the selection of students based on their intellectual abilities. Tannir in international journals states [14]that character education benefits groups who are intellectually less capable than those who are intellectually capable. For students who have less capable intellectuals can improve their quality through the planned character education in each curriculum.

\section{CONCLUSION}

Character education can be accepted by students, if the teacher is able to provide good examples to students. In addition to strategies that need to be planned by the teacher to shape the character of students, there needs to be good management in the implementation of the strategy management. In the strategy management process through three stages namely planning that includes the creation of the vision, mission, and objectives of the strategy, implementation is part of the implementation of planning that has been prepared by the teacher, and the last is an evaluation that is expected to show good results from strategy management. The most important thing in the management of student character 
formation strategies is cooperation between teachers in shaping the character of students

\section{REFERENCES}

[1] S. Darmiatun, "Implementasi Pendidikan Karakter di Sekolah," Yogyakarta: Gava Media, 2013.

[2] R. Bogdan and S. Biklen, "Qualitative research for education: An introduction to theory and practice," Needham Heights, MA: Allyn and Bacon, 2007.

[3] R. David Fred, "Manajemen Strategis Konsep," Salemba Empat: Jakarta, 2009

[4] J. J. Ferreira, M. L. Raposo, and E. W. Mainardes, "Strategy and strategic management concepts: are they recognised by management students?," Economics and Management, 2014.

[5] L. Agung, "Character Education Integration in Social Studies Learning," Historia: Jurnal Pendidik dan Peneliti Sejarah, vol. 12, pp. 392-403, 2018.

[6] A. Pala, "The need for character education," International Journal of Social Sciences and Humanity Studies, vol. 3, pp. 23-32, 2011.

[7] N. Novianti, "Teaching Character Education to College Students Using Bildungsromans," International Journal of Instruction, vol. 10, pp. 255-272, 2017.
[8] A. Agboola and K. C. Tsai, "Bring Character Education into Classroom," European journal of educational research, vol. 1, pp. 163 170, 2012.

[9] N. Park, C. Peterson, and M. E. Seligman, "Strengths of character and well-being," Journal of social and Clinical Psychology, vol. 23, pp. 603-619, 2004

[10] A. H. Alharthy, H. Rashid, R. Pagliari, and F. Khan, "Identification of strategy implementation influencing factors and their effects on the performance," 2017.

[11] W. Althof and M. W. Berkowitz*, "Moral education and character education: Their relationship and roles in citizenship education," Journal of moral education, vol. 35, pp. 495-518, 2006

[12] A. Hidayati, M. Zaim, K. Rukun, and D. Darmansyah, "The Development of Character Education Curriculum for Elementary Students in West Sumatera," International Journal of Education and Research, vol. 2, pp. 189-198, 2014.

[13] M. Aslan, "Handbook of moral and character education, edt. Larry P. Nucci and Darcia Narvaez," International Journal of Instruction, vol. 4 pp. 211-214, 2011

[14] A. Tannir and A. Al-Hroub, "Effects of Character Education on the Self-Esteem of Intellectually Able and Less Able Elementary Students in Kuwait," International journal of special education, vol. 28, pp. 4759, 2013. 